\title{
Adapting English lessons to raise culture awareness in an EFL classroom
}

\section{Adaptación de las lecciones para concienciar sobre la cultura en una clase de inglés como lengua extranjera}

Jessica Valentina Galimberti. ${ }^{1}$, Silvia Elizabeth Cárdenas Sánchez. ${ }^{2}$, \& Ivonne Lorena Ochoa Jarrín ${ }^{3}$

Recibido: 19-04-2019 / Revisado: 25-05-2019 /Aceptado: 29-06-2019/ Publicado: 15-07-2019

\begin{abstract}
.
DOI: https://doi.org/10.33262/cienciadigital.v3i3.1.684

Ecuador is known as a multicultural country as there is a permanent multiethnic and edifying interaction between people in varied contexts, and the classroom is not the exception. Nevertheless, when learning a foreign language, as for instance English in Ecuador; the cultural aspect becomes more apparent since it implies the study of another language, which represents another culture. This article review examines the influence of students' cultural background in English as a foreign language (EFL) learning in Ecuador. Relevant studies were reviewed to get insights and experiences from foreign language learning contexts similar to the Ecuadorian one. It also addresses the importance of considering students' diverse backgrounds in lesson planning. Thus, it could provide with some selected activities for English teachers to apply during language formal instruction
\end{abstract}

Keywords: cultural awareness, EFL, teaching strategies

\section{Resumen.}

Ecuador es conocido como un país multicultural; en consecuencia, hay una interacción cultural continua entre las personas en diferentes contextos, y las aulas no son la excepción. Sin embargo, cuando se aprende una lengua extranjera, como es el caso del inglés en el Ecuador, el aspecto cultural se hace más evidente, ya que implica el estudio

\footnotetext{
${ }^{1}$ Escuela Superior Politécnica de Chimborazo, Sede Morona Santiago. Macas, Ecuador. jessica.galimberti@espoch.edu.ec

${ }^{2}$ Escuela Superior Politécnica de Chimborazo, Sede Morona Santiago. Macas, Ecuador. silvia.cardenas@espoch.edu.ec

${ }^{3}$ Escuela Superior Politécnica de Chimborazo, Sede Morona Santiago. Macas, Ecuador. ivonne.ochoa@espoch.edu.ec
} 
de otra lengua, que representa otra cultura. Esta revisión de literatura examina la influencia del aprendizaje cultural de los estudiantes en inglés como lengua extranjera (EFL) en Ecuador. Se revisaron los estudios relevantes para obtener información y experiencias de contextos de aprendizaje de idiomas extranjeros similares a los ecuatorianos. También aborda la importancia de considerar los diversos antecedentes de los estudiantes durante la planificación de las lecciones. Por lo tanto, proporcionará algunas actividades seleccionadas para que los profesores de inglés apliquen durante la instrucción formal del idioma.

Palabras claves: conciencia cultural, EFL, estrategias de enseñanza.

\section{Introduction.}

For years, our education has been divided into two groups. The first group was Bilingual Education for those students who belonged to another ethnic group and spoke languages other than Spanish. Under this type of instruction, students could use their first language (L1). The second group was Hispanic Education for mestizo students. Under this type of education, teachers used Spanish in the classroom.

Today, this has changed because the Ecuadorian president joined both kinds of education into a single one. This has brought big problems to teachers because they are not prepared to deal with culturally diverse students, especially with students whose native language is other than Spanish.

English is a mandatory subject in the curriculum, starting in the eighth year of Basic Education. Teaching English as a Foreign Language is very important in our educational system and, according to Ecuadorian In-Service English Teacher Standards (Inglés, 2012), culture is one of the five domains of the language. It explains that teachers must understand and teach Ecuadorian culture and other cultures using different resources like the internet (Inglés, 2012).

Teachers, independently of their place of work, must consider students' cultural backgrounds and help them achieve their goals. However, in most cases, it requires making some cultural adaptations, looking for additional resources, or creating materials.

Many teachers consider that including culture in language instruction is a waste of time. Consequently, they work with the curriculum given and avoid using extra-curricular materials to adapt their teaching process. Furthermore, in Ecuadorian public schools, English teachers are required to use the English text provided by the Ministry of Education. Even though it is a book with great activities, it does not contain facts related to Ecuadorian culture.

Ecuador is a multicultural country. It does not occupy a large territory; however, it has a vast amount of traditions, languages, legends, and historical places in it. Since Ecuador possesses such characteristics, culture must have serious consideration in educational contexts and 
above all in foreign language classes because a language is the representation of a culture. Therefore, it would be interesting to compare the Ecuadorian educational setting with similar settings in other countries to put on a balance what has been done and what is still missing to do to become more effective at dealing with the reality of having culturally diverse students in the EFL classrooms.

The use of extracurricular materials in an English class may increase cultural awareness and the opportunities to develop language skills. Furthermore, teachers can create a classroom environment, which includes learners' participation and cultural integration since most schools in Ecuador work with students who come from different cultures. If teachers take into consideration cultural diversity, students will have a sense of meaningfulness in their English classes.

\section{Literature review}

\section{Multicultural education}

According to Baptiste (1995), multicultural education is "a comprehensive philosophical reform of the school environment essentially focused on the principles of equity, success, and social justice for all students" (p. 5). Equity is when the curriculum and instruction are adapted for diverse students. Success is when the school represents all kinds of students. Finally, social justice occurs, and the learning is based on reflection about social change (Baptiste, 1995, p. 5).

Furthermore, Banks (2007) mentions that multicultural education is an idea, an educational reform movement, and a process. The idea is that students deserve equal opportunities in schooling (p. 3). The reform movement ensures equal opportunities for everybody. Finally, the process continually incorporates or improves (Banks, 2007. p. 4).

The implementation of multicultural education has faced a lot of problems throughout history because people and movements have had to fight to ask for better opportunities. The civil rights movements have been a relevant element in multicultural education. Women asking for the same opportunities in education, minority groups' desire to better schooling opportunities and changing of the curriculum must be considered in integrating culture in education (Banks, 2007).

Even when the United States of America and the United Kingdom do not have a core culture because their population has different origins, segregation and discrimination are still evident in educational contexts (Banks, 2007). Ecuador faces a similar situation since curriculum adaptations, and teachers' readiness has not been addressed yet. 
According to Díaz-Rico and Weed (2002), culture is everything around us where people get their identity. Furthermore, Banks (2007) defines culture as a set of beliefs, symbols, and interpretations that belong to a group and how the members of a community use artifacts, tools or other cultural elements (p. 8).

Moreover, Darder (1991) categorizes culture as language, cultural values or value orientation, heritage, cultural artifacts, and cognitive styles. "The meaning and nature of culture, as such, is derived out of the lived experiences of different social groups and the practical activities of ownership, control, and maintenance of institutions" (Darder, 1991, p. 29). Teachers must be aware of these changes because they affect learners (Wlodkowski \& Ginsberg, 1995, p. 9). Additionally, multicultural teachers are aware of their responsibility in educating diverse learners (Bennett, 2003, p. 41-42).

\section{Instructional adaptations in Ecuadorian English curriculum}

According to the third domain of Ecuadorian In-Service English teachers (2012), "Teachers know, understand, and use evidence-based practices and strategies related to planning, implementing, and managing standards-based English and content instruction." Also, teachers have to select, adapt, and use materials that must help students in the learning process to acquire the English language (P. 7). Based on these standards, teachers have the opportunity to look for extracurricular materials that are going to help students to learn a foreign language. However, teachers must make the corresponding adaptations at the planning stage.

Banks (2007) argues that "when formulating plans for multicultural education, educators should conceptualize the school as a micro culture that has norms, values, statuses, and goals like other social systems" (p.24). However, implementing accommodations in a curriculum does not ensure multicultural education; it depends on teachers' attitudes about diverse groups in order to implement an innovative program (Banks, 2007, p. 22).

A teacher must be prepared to work with multi-ethnic students to provide a multicultural curriculum. They have to be critical, learn students' backgrounds, create a democratic classroom and self-reflect about culture issues. Therefore, Ecuadorian education system has been evolving since society has been changing at the same time during the past few decades (Darder, 1991). On the other hand, non-English teachers believe that culture is not their concern as considered ethnicity and racism, so that they misunderstand the importance of including multicultural education in their lesson plans.

Banks (2007) argues that, implementing multicultural education involves five dimensions to consider. The first one is content integration, in which teachers should provide examples and content related to ethnicity and culture. However, in subjects like English, it is easy to 
implement this, but in others like Math, it is harder, because educators have to be creative and adapt their lesson plans including cultures (p. 20). The second principle is knowledge construction process, where teachers help students to identify the importance of culture in each content of study. In the third dimension, prejudice reduction, teachers need to plan activities to help students understand and respect ethnic and cultural groups (Gray, 2007). Finally, empowering Ecuadorian education standards means allowing students participation in each activity (p. 21-22). As well, Boyer states that "increased diversity is now the basis for a transformed curriculum" (p. 50). Therefore, a meticulous selection of materials to be used in the EFL classroom is very important to reach academic achievement and ethnic growth (Boyer \& Baptiste, 1996, p. 52-8).

According to Martins and White (2013), students' culture may differ from one another and teachers have to be alert to act properly in order to avoid conflicts. Another way of incorporating culture can be forming workstations where students can present topics about their culture as music, food, and important characteristics. By doing these activities, the whole class could learn about culture from their classmates. Finally. Martins and White (2003) conclude that "schools must offer learning environments that welcome ethnically diverse students, practice culturally responsive teaching, and promote academic success for all students" (Martins-Shannon \& White, 2012).

Furthermore, Nieto (2007) argues that culturally responsive education approach is a tool to avoid student's failure in multicultural learning. Students' achievement occurs when school's reforms are anti racist and anti-biased, and when teachers identify students' talents and strengths or when teaching and learning are connected and based on high expectations for all the students (Nieto, 2007).

\section{Strategies}

After reviewing some literature about integrating cultural curriculum material in English classes, it is necessary to look for strategies that could help teachers to implement them. The following strategies could help teachers to raise cultural awareness in an EFL class.

\section{Traditions Families have}

This strategy helps to describe traditions on students' families (Warner, Lynch, Nabors, \& Simpson, 2008).

Skills: Listening, speaking, writing

\section{Description}

Teacher asks students to think about some dates that Ecuadorian people celebrate such as Christmas, Carnival, and Eastern among others. Then, the teacher encourage students to share special things that their family does during those holidays. They can present their work using 
pictures, essays or videos if it is possible. Finally, the teacher discusses with students about their presentation. It could be a great strategy to apply in English when the topic lesson is family members.

\section{Nutritionally sounds diets.}

Most of English books contains topics related with food for almost each level Therefore, this strategy could help teachers to know students' food habits, and learn about other cultures.

Skills: Listening, speaking, writing, reading

\section{Description}

Teacher divides the class in groups of 5 students. Then students have to select some foods and write in a chart. After that, each student chooses one item and complete the table. Finally, they present their choices to the classroom.

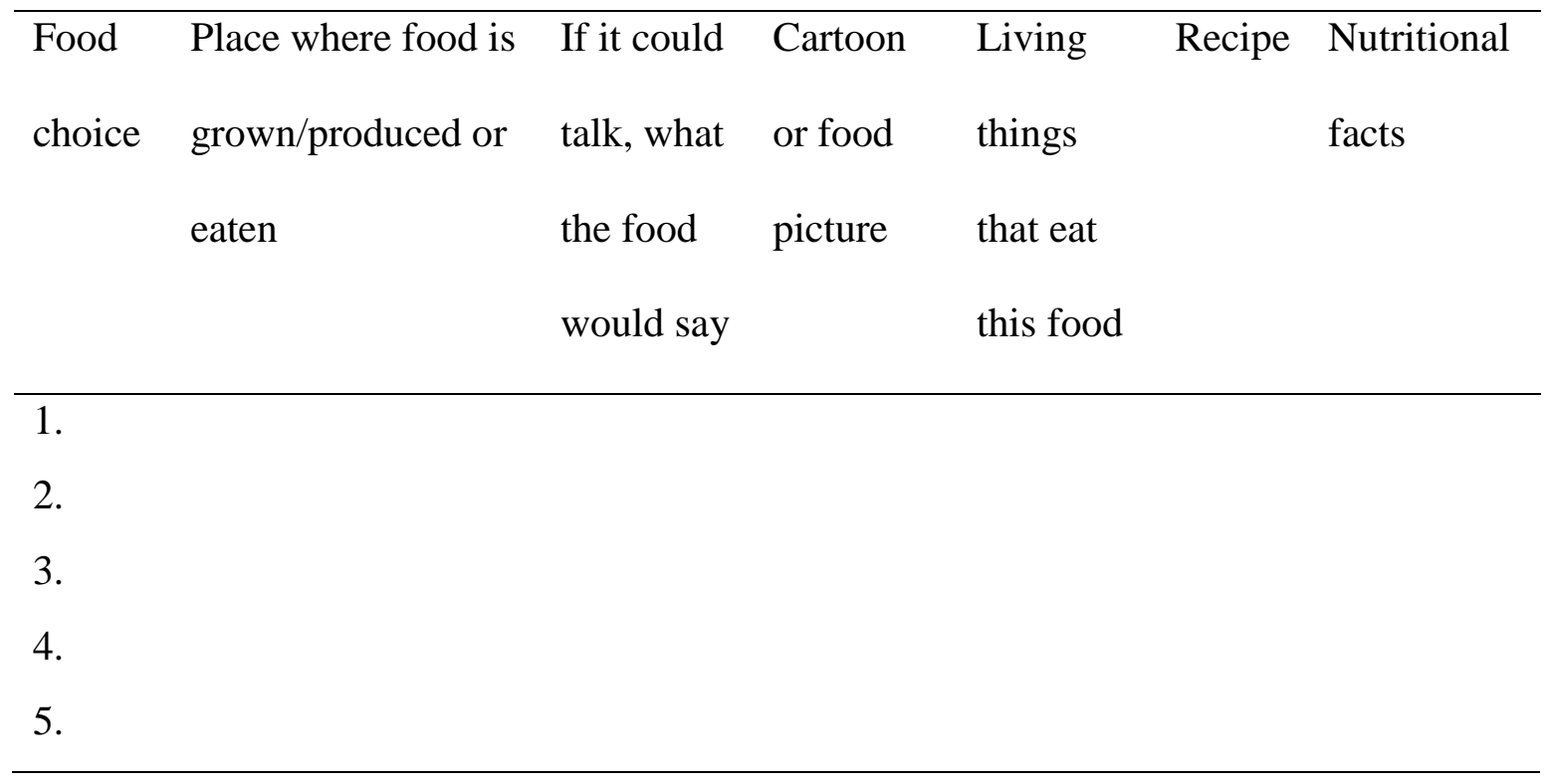

\section{Capturing cultural bias}

Some strategies can be used at the beginning of the class like a warm up and could help to raise awareness of the importance of students' cultural behaviors.

Skills: Listening, speaking, writing and reading

\section{Description}

Teacher provides to students some adjectives that describe culturally learned behaviors. Students choose 5 adjectives to describe people that they would like to be around them. Then they choose 5 adjectives to describe people that they would not like to be around them. Finally, students discuss the results in groups and teacher could ask some questions like; Why 
didn't you like any behaviors? Why did you like some behaviors? Where did you learn to like and dislike those behaviors?, and so on. (Pedersen, 2004, p. 15)

\section{A personal culture history}

Teacher can help students become more aware of the role of culture in their lives by asking them to describe their own personal cultural history (Pedersen, 2004, pág. 240)

Skills: Listening, speaking, writing, and reading

\section{Description}

This activity can be sent as homework. Students have to reflect on their cultural backgrounds. Teacher can give some questions to guide their work. This questions can be: How would you describe your culture?, Who was the most significant culture teacher in your life?, How has your culture changed over time?, How many different cultures do you belong to?

\section{All about me}

Some strategies help teachers to know their students. This activity could help teachers to identify diversity in the classroom

Skills: Listening, speaking, writing and reading

\section{Description}

Teacher asks students to present their family in front of the class. Students can use pictures, family photos or an artifact that represents their family. While they are talking about their family, teacher can do a diagnostic assessment of students' backgrounds (Cooper \& Levin, 2011, p. 40)

\section{Implications}

Ecuador as a multicultural country has many advantages that can be linked in the learning process. However, teachers just want to develop the curriculum established by the government without any change. If teachers do not meet all of the students necessities, such as abilities, cultural and linguistic differences; the results would not be positive both sides; nor teachers' nor students'.

As a consequence of this attitude and decision, the percentage of students that fail the exams is higher; so that changing teachers' traditional way of thinking would be the best solution and way to finally start working and aiming the students' success in all subjects. This is a process in which educators have to become aware of Ecuador multicultural and multiethnic perspectives and use mentioned treasure in their daily lesson plans.

Modifying the curriculum would be a hard implication from the Ecuadorian teachers' point of view, but it is necessary to include in the lesson plans, culture and standards that a good education implies. Mainly, it is necessary to assess students preparing a diagnostic test in order to analyze their level of English. In conclusion, Ecuadorian education has to adjust 
some aspects of its academic curriculum and in this process everybody has to contribute, especially English teachers need to be prepared and trained for any situation could occur and overall understand that every student deserves equal opportunities.

\section{References.}

Banks, J. A. (2007). Multicultural education: Characteristics and goals. In J. A. Banks, \& C. McGee Banks, Multicultural Education. Issues and perspectives (pp. 3-30). Hoboken: John \& Sons, Inc.

Bennett, C. I. (2003). Comprehensive multicultural education. Theory and Practice. Boston: Pearson education, Inc.

Boyer, J. B., \& Baptiste, H. (1996). Transforming the curriculum for multicultural understanding. San Francisco: Caddo Grap Press.

Cooper, J. E., \& Levin, B. B. (2011). Developing critical cultural competence. Oaks: Corwin.

Darder, A. (1991). Culture and power in the classroom. London: Bergin \& Garvey.

Díaz-Rico, L. T., \& Weed, K. Z. (2002). The cultural, language, and academic development handbook. Boston: Allyn \& Bacon.

Gray, D. L. (2007). Encouraging multicultural diversity in the curriculum. In M. A. Trent, T. Grizzie, M. Sehorn, A. Lang, \& E. Rogers, Religion, culture, curriculum, and diversity in 21st century America (pp. 47-55). Maryland: University Press of America, Inc.

Inglés, E. T. (2012). Ministerio de Educación del Ecuador. Retrieved from www.educacion.gob.ec:

http://educacion.gob.ec/wpcontent/uploads/downloads/2012/09/estandares_2012_ingles_opt.pdf

Martins-Shannon, j., \& White, M. (2012, Winter). EBSCO HOST. Retrieved from www.ebscohost.com: http://web.a.ebscohost.com/ehost/detail?sid=b98719a4-49a1438a-8995-

78112d32b379\%40sessionmgr4002\&vid=1\&hid=4101\&bdata=JnNpdGU9ZWhvc3Qt bG12ZQ\%3d\%3d\#db=eft\&AN=91690210

Pedersen, P. B. (2004). 110 experiences for multicultural learning. Washington, DC: American Psychological Association.

Warner, L., Lynch, S., Nabors, D. k., \& Simpson, C. (2008). Themes for inclusive classrooms. Lesson plans for every learner. Beltsville: Gryphon House, Inc.

Wlodkowski, R. J., \& Ginsberg, M. (1995). Diversity \& Motivation. Culturally responsive teaching. San Francisco: Jossey-Bass. 


\section{PARA CITAR EL ARTÍCULO INDEXADO.}

Galimberti, J., Cárdenas Sánchez, S., \& Ochoa Jarrín, I. (2019). Adapting English lessons to raise culture awareness in an EFL classroom. Ciencia Digital,3(3.1), 158-166. https://doi.org/10.33262/cienciadigital.v3i3.1.684

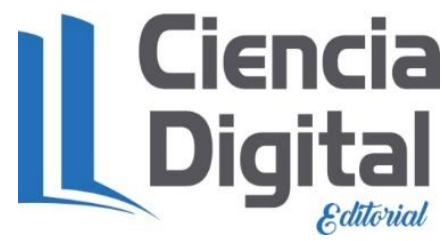

El artículo que se publica es de exclusiva responsabilidad de los autores y no necesariamente reflejan el pensamiento de la Revista Ciencia Digital.

El artículo queda en propiedad de la revista y, por tanto, su publicación parcial y/o total en otro medio tiene que ser autorizado por el director de la Revista Ciencia Digital.
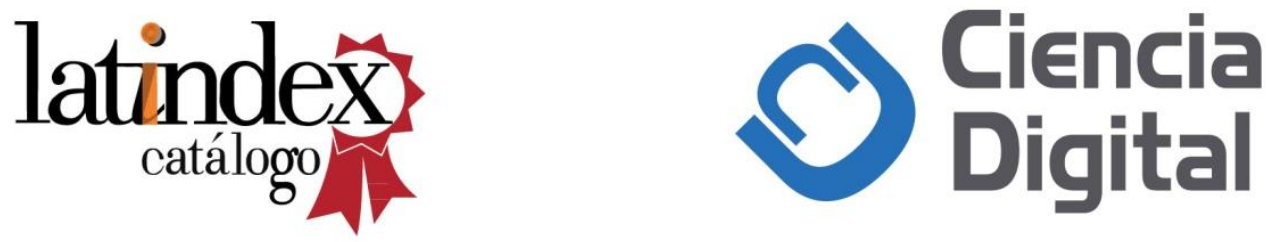